\title{
液面動摇の非線形性を考慮したTLD-構造系の風応答解析 WIND RESPONSE ANALYSIS OF TLD-STRUCTURE SYSTEM CONSIDERING NONLINEARITY OF LIQUID MOTION
}

\author{
若原敏 裕*, 大山 巧**, 藤井邦雄*** \\ Toshihiro WAKAHARA, Takumi OHYAMA and Kunio FUJII
}

\begin{abstract}
A nonlinear Tuned Liquid Damper (TLD)-structure interaction model has been developed to investigate the effect of nonlinearity in TLD, and to simulate the wind-induced response of TLDstructure system. The interaction model employed is a combination of the model which is based on the Boundary Element Method (BEM), for simulating the liquid motion in TLD container, and Multi Degrees of Freedom (MDOF) for structure. The numerical results are compared with experimental records and obserbations records. The validity of proposed TLD-structure interaction model is confilmed by the results of those comparisons. Furthermore, from the numerical simulations, the nonlinear effects by TLD which affected structure response and vibration characteristics are clarified.
\end{abstract}

Keywords : damper, vibration control, wind-induced vibration, hydrodynamic force, nonlinear, interaction

液体ダンパー，振動制御，風振動，流体力，非線形，相互作用

\section{1.はじめに}

構造物の高層化や長大化に伴い, 風外乱による振動は, 使用性や快適性の低下，限定的な調和振動による疲労障 害, さらには，破壊的な発散振動など，樣々な問題を引 き起こす可能性がある。現在,これらの解決手段として, 制振装置による振動制御が注目されており, 目的に応じ, 数多くの制振装置に関する研究・開発が行われている。

それらの中でも，液体のスロッシング現象を利用する Tuned Liquid Damper (TLD) は, 従来からの固体質 量を用いる Tuned Mass Damper (TMD) 形式の制振 装置と比較して, 設置が容易で微振動レベルから確実に 制振効果を発揮できる長所があり，ここ数年来，活発な 研究活動が行われている11 20)。

実構造物への適用例として,これまでに, タワー, 展 望台, 空港管制塔などの風による振動対策 ${ }^{21,3,6)}$ や斜張 橋主塔の振動対策 91 .101 が挙げられ, それらの効果は十分 に確認されている。また, 今後も, 超高層インテリジェ ントビル, 超高層住宅あるいは超高層ホテルなどの日常 の使用性や居住性が建物性能に直接反映される建物, さ らには，長大橋の主塔や主妳の風による振動対策なよ゙，
幅広い構造物への適用が期待されている。

TLD を設計し構造物への設置を考える場合, 固有周 期の同調や減衰定数の設定さらには制振効果の評価之 いった検討に，TLD の制振原理が TMD 亡基本的に同 様であるという理由から，TMD の設計に用いられる質 点置換モデルを適用する場合が多い111 13!。

一般に，液体が深い状態では，TLD に相当する質点 の等価質量や等価減衰の評価には, Housner の線形ス ロッシング理論に基づく質点モデルを利用できるが, 液 体が浅い TLD では, 容器内のスロッシング現象に波の 非線形性の影響が強く現れるため, 等価な質点系への置 換は難しい。

これまでは, 取扱いの簡便さから, TLD の液面動摇 に対して, 想定した加振レベルでの振動実験を行い, 実 験より得られた等価質量と等価减衰を用い，近似的な等 価質点モデルに置換することが行われてきた。しかし， 今後の実用化に向け, 表面波動の幾何学的な非線形性や 減衰の振幅依存性など, TLD の液面動摇に関する非線 形現象を厳密に考慮できる解析モデルの開発が望まれて いる。

\footnotetext{
* 清水建設技術研究所 研究員 ·工修

** 清水建設技術研究所 研究員

*** 風工学研究所 所長 · 工博 (元 清水建設技術研究所 研究部長)
}

Research Engineer, Institute of Technology Shimizu Corporation, M. Eng.

Research Engineer, Institute of Technology Shimizu Corporation

President, Wind Engineering Institute Corporation, Dr. Eng. 
藤野らは, 液面動摇の非線形性を考慮するため, 清水・ 葉山ら ${ }^{24)}$ が提案する非線形長波理論（浅水波理論）に基 づく流体解析モデルを応用し，TLDと 1 質点にモデル 化した構造物の連成応答を求める数值シミュレーション 法を提案している。また, 提案する解析方法が, 定常な 強制変位による実験結果とよく一致することを示してい

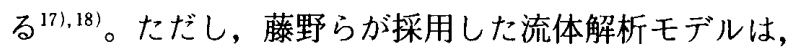
長波近似を採用しているため，風による自励振動のよう な低振動数の定常調和外力に対しては, 十分な解析精度 を持つが, 高振動数成分を含むランダム性の強い外力に 対しては, 液面付近の厳密な非線形挙動を考慮できない ため,その適用が難しい。

本研究は，このような観点から，風による超高層ビル や塔状構造物のガスト応答などランダム性の強い応答解 析問題に適用可能な TLD-構造系の連成応答解析法につ いて検討するものである。また，これまでは，ほとんよ゙ 詳細な検討が行われていなかった構造系の応答に及ぼす 夜面動摇の非線形性の影響についての考察も行う。

まず，TLD と構造物の相互作用系に関する定式化を 行い, TLD-構造系の連成応答を求める数值解析法につ いて説明する。本研究の流体力の解析には, ランダムな 外力に対応するため, 大山ら ${ }^{21,22)}$ が提案する境界要素法

(BEM) に基づく非線形波動解析モデルを用いてい $る^{20)}$ 。この方法では, TLD 内の非線形波動を速度ポテ ンシャルに関する境界值問題として定式化しているた め, 長波理諭に基づく解析方法とは異なり, すべての振 動数範囲で適用でき, また, 非線形性の強い波動場に対 する取扱いも可能である。

次に，本解析モデルの妥当性について検証するため， 定常調和外力に対する振動実験結果との比較を行い, 実 験結果 ${ }^{171}$.18) と解析結果が良く一致することを示す。また, 液面動摇の非線形性が構造系の応答に及ぼす影響を明ら かにするため, 共振振動数付近の構造系の応答特性之液 面動摇の非線形性について考察する。

最後に, 定常ランダムな外力に対する適用性について 検討するため, 横浜マリンタワーを例に, 適当な変動風 力を仮定した時系列応答解析を行い, 風観測記録との対 比から, ランダム性の強い外力に対しても十分適用でき ることを示す。さらに, 今後 TLD の最適設計において 重要となる TLD の制振効果とその減衰特性の関係につ いても考察する。

\section{2. 応答解析理論}

\section{1 相互作用系の定式化}

本研究では, Fig. 1 に示すような TLD-構造系の相互 作用モデルを考えることにする。Fig. 1 の相互作用モデ ルは, TLD 容器内の液面波動に対しては BEM に基ゔ く非線形波動モデルを応用し，構造系を適当な自由度の
多質点・ばね系に置換したものである。TLD-構造系の相 互作用は, TLD の流体力と構造物の応答との間の非線 形連成振動問題として定式化することができ, Fig. 1 の 相互作用モデルの振動方程式は, 次式のように表すこと ができる。

$$
\begin{aligned}
& {[M]\left\{\ddot{u}_{s}\right\}+[C]\left\{\dot{u}_{s}\right\}+[K]\left\{u_{s}\right\}=\{F\}+\left\{\alpha \mid D_{h y d} \cdots(1)\right.} \\
& D_{h y d}=N_{D} \int_{s_{w}} p d z \quad\left(S_{W}=S_{W 1} \cup S_{W_{2}}\right) \cdots \cdots \cdots(2)
\end{aligned}
$$

式（1）中の $[M],[C],[K]$ は, 構造系の質量マトリク ス, 減衰マトリクスおよび岡性マトリクスである。また, $\left\{u_{s}\right\}$ は構造系の変位ベクトル, $\{F\}$ は外力ベクトルであ り， $D_{h y d}$ は構造系に制振力として作用する TLD の流 体力である。 $|\alpha|$ はTLD を設置した質点が1, それ以外 がすべて0であるような列べクトルである。式（2）中 の $N_{D}$ は設置した TLD 容器の個数であり, $p$ は TLD 容器側壁に分布する動液圧である。式（2）の積分領域 $S_{w}\left(=S_{w_{1}} \cup S_{w_{2}}\right)$ は, Fig. 2 に示す矩形容器の側壁 $S_{w_{1}}, S_{w_{2}}$ を表し, 容器側壁に作用する動液圧 $p$ は, 以 下で述べる非線形波動解析から求めることができる。

いま, Fig. 2 に示す振動方向幅 $L$ の容器内における 液深 $h$ の流体運動を考える。容器内の液体を非圧縮, 非粘性とし, 流体運動を非回転であると仮定すれば, 流 体運動に伴う動液圧 $p$ は, 速度ポテンシャル $\phi(x, z, t)$

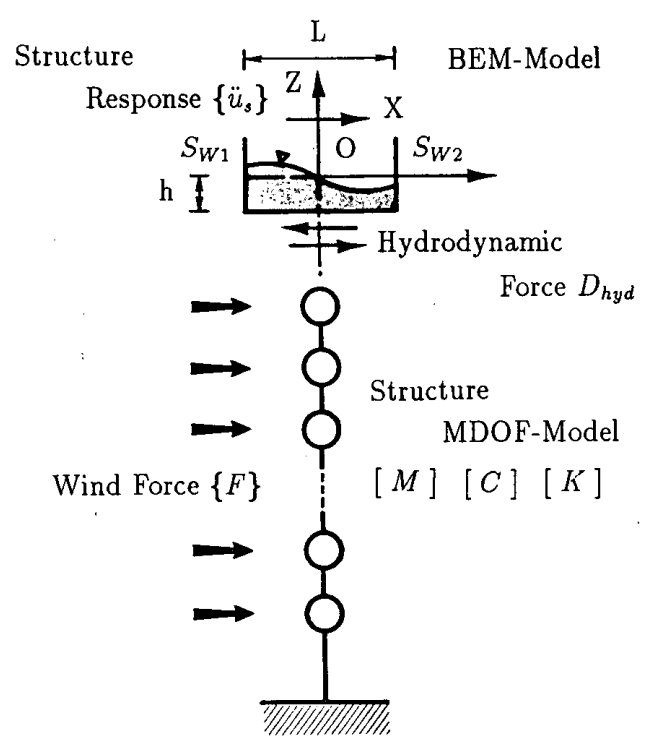

Fig. 1 TLD-Structure System

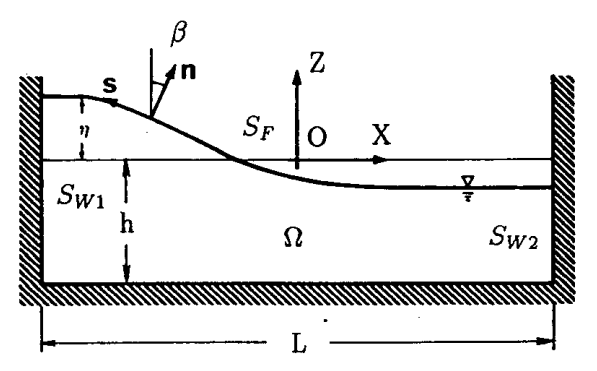

Fig. 2 TLD Container and Parameters 
により次式で求められる。

$$
p=-\rho\left[\frac{\partial \phi}{\partial t}+\frac{1}{2}\left(\frac{\partial \phi}{\partial z}\right)^{2}+\gamma \phi+\{\alpha\}^{T}\left\{\ddot{u}_{s} \mid x+g z\right]\right.
$$

式（3）中の $\rho$ は液体密度, $g$ は重力加速度であり, ${ }^{r}$ は転置を意味する。容器内の流体運動は, 速度ポテン シャル фに関する境界値問題を解くことにより求める ことができる。この場合の基礎方程式は次式で表される。

$$
\frac{\partial^{2} \phi}{\partial x^{2}}+\frac{\partial^{2} \phi}{\partial z^{2}}=0 \quad(\text { in } \Omega)
$$

式（4）の境界条件は, 容器側壁および容器底面におい て,

$$
\left.\begin{array}{ll}
\frac{\partial \phi}{\partial x}=0 & \left(\text { on } S_{w_{1}}, S_{w_{2}}\right) \\
\frac{\partial \phi}{\partial z}=0 & (\text { at } z=-h)
\end{array}\right\}
$$

また，自由表面における運動学的な条件として，

$$
\frac{\partial \phi}{\partial n}=\frac{\partial \eta}{\partial t} \cos \beta \quad\left(\text { on } S_{F}\right)
$$

さらに, 力学的な条件 (圧力方程式) として,

$$
\begin{aligned}
& \frac{\partial \phi}{\partial t}+\frac{1}{2}\left\{\left(\frac{\partial \phi}{\partial n}\right)^{2}+\left(\frac{\partial \phi}{\partial s}\right)^{2}\right\} \\
& \quad+\gamma \phi+\{\alpha\}^{T}\left\{\ddot{u}_{s}\left\{x+g \eta=0 \quad \text { (on } S_{F}\right)\right.
\end{aligned}
$$

である ${ }^{21}$ 。これらの境界条件の内, 液面波動の幾何学的 な非線形性を表しているのは, 式（6）と式（7）であ る。

式（5)～式（7) において, $\eta(x, t)$ は鉛直上向きを 正とした平均液面からの液面変動量, $n, s$ は領域 $\Omega$ を 取り囲む境界上での外向き法線方向および接線方向, $\beta$ は水面上の法線ベクトルと鉛直軸のなす角度である。

式（7）中の $\gamma \phi$ は表面波動の減衰項を表しており, 速度に比例する等価減哀項として評価している。 $\gamma$ は減 衰係数であり，その值は，ほとんど実験的に決められて いる。ここでは, Lepelletier and Raichen"25)にならい, 次式で評価することにした。

$$
\gamma=\frac{1}{h} \sqrt{\frac{\nu \omega}{2}}\left(1+\frac{2 h}{b}+c\right)
$$

ただし， $b$ は容器の奥行き幅, $\nu$ は液体の動粘性係数, $c$ はSurface Contaminationによる減衰項であり,ここ

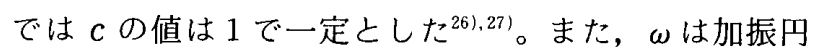
振動数を意味しているが, 非定常な外力に対する応答解 析を行う場合, 必ずしも唯一つの加振円振動数 $\omega$ を限 定することはできない。本研究では，スロッシングの基 本固有円振動数 $\omega_{L}=\omega_{n(n=1)}$ を与えることにした。なお, $\omega_{n}$ は次式で表される。

$$
\omega_{n}=\sqrt{\frac{n \pi g}{L} \tanh \left(\frac{n \pi h}{L}\right)} \quad(n=1,2, \cdots)
$$

式（1）（９）で定式化された連成振動の時刻歴応答
は, TLD の流体力 $\{\alpha\} D_{h y d}$ 之構造物の加速度応答 $\left\{\ddot{u}_{s}\right\}$ の 間で, 前時刻ステップの流体力を初期值とする収束計算 から求めることができる。

\section{2 流体力解析の概説}

Fig. 2 の流体領域 $\Omega$ に 2 次元のグリーン公式を適用 する。このとき $\Omega$ を取り囲む境界面 $S$ 上の点 $P\left(x_{p}, z_{p}\right)$ の速度ポテンシャル $\phi(P)$ は, 以下のように表せる21。

$$
\begin{aligned}
& \phi(P)=-\frac{1}{\alpha^{*}(P)} \int_{s}\left\{\phi \frac{\partial G}{\partial n}-\frac{\partial \phi}{\partial n} G\right\} d s \\
& G(P, Q)=\ln (1 / r)+\ln (1 / \bar{r}) \\
& r=\sqrt{\left(x_{Q}-x_{P}\right)^{2}+\left(z_{Q}-z_{P}\right)^{2}} \\
& \bar{r}=\sqrt{\left(x_{Q}-x_{P}\right)^{2}+\left(z_{Q}+z_{P}+2 h\right)^{2}}
\end{aligned}
$$

ただし， $Q\left(x_{q}, z_{q}\right)$ は $S$ 上の点の座標であり, 式 (10) 中の係数 $\alpha^{*}(P)$ は境界形状から定まる係数である ${ }^{211}$ 。

式（10）に式（7）以外の境界条件式を代入し，さら に $z=-h$ で $\partial G / \partial n=0$ であることを考慮すれば, 次 式が得られる。

$$
\begin{aligned}
\phi(P)= & -\frac{1}{\alpha^{*}(P)} \mid \int_{s_{w \cup s_{F}}} \phi \frac{\partial G}{\partial n} d s \\
& \left.-\int_{s_{F}} G \frac{\partial \eta}{\partial t} \cos \beta d s\right\} \ldots . .
\end{aligned}
$$

また, 式（7）については, 重み付き残差法により境界 積分方程式に変換する。式（7）に式（6）を代入し, 両辺に任意の重み関数 $\theta$ をかけ， $S_{F}$ 上で積分すること により次式が得られる。

$$
\begin{gathered}
\int_{s_{F}} \Theta\left[\frac{\partial \phi}{\partial t}+\frac{1}{2}\left\{\left(\frac{\partial \eta}{\partial t} \cos \beta\right)^{2}+\left(\frac{\partial \phi}{\partial s}\right)^{2}\right\}\right. \\
+\gamma \phi+\{\alpha\}^{T}\left\{\ddot{u}_{s} \mid x+g \eta\right] d s=0 \ldots \ldots \ldots \ldots
\end{gathered}
$$

式（13）（14）の境界積分方程式を線形要素を用いて 空間的に離散化し, 重み関数 $\Theta$ の任意性を考慮すると,

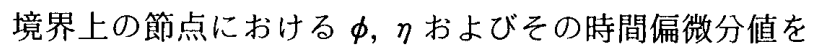
未知数とする連立方程式が得られる。これらを各時刻ス テップで解くことにより, $\phi$ および $\eta$ が求められ, 動 液圧 $p$ が式 (3) 加ら計算できる。構造系の加速度応 答 $\left\{\ddot{u}_{s}\right\}$ に対するTLD の流体力 $D_{h y d}$ は, 各々の境界要 素における動液圧 $p$ の積分值から, 次式のように求め られる211。

$$
D_{h y d}=-N_{D} \int_{s_{w_{1}}} p d z+N_{D} \int_{s_{w_{2}}} p d z
$$

なお，境界積分方程式の空間的な離散化と各時刻ステッ プでの境界形状に関する収束計算についての詳細は文献 21）に襄るものとする。

\section{3 応答の直接積分法}

非線形振動問題における応答の直接積分は, 高次の微 小項まで考慮した差分スキームを非常に小さい時間間隔 で適用する場合が多い。本研究では 4 次の微小項まで考 慮した変位推定タイプの差分スキームを用いることにす 
る。

時刻 $t+\Delta t$ および時刻 $t-\Delta t$ における変位忘答を Taylor 展開し， $\Delta t$ に関する 5 次以上の微小項を無視し て両者を加えると, 次のような関係式を得る。

$$
\begin{aligned}
\left\{u_{s}\right\}_{t+\Delta t}= & -\left\{u_{s t_{t-\Delta t}}+2\left\{u_{s i t}+\Delta t^{2}\left\{\ddot{u}_{s}\right\}_{t}\right.\right. \\
& +\frac{1}{12} \Delta t^{4}\left\{u_{s}^{(4)}\right\}_{t} \ldots \ldots \ldots \ldots \ldots \ldots \ldots
\end{aligned}
$$

式 (16) 中の $\left\{u_{s}^{(4)}\right\}$ は, 時刻 $t$ に関する 4 次の微分項で あり，これは，時刻 $t+\Delta t$ および時刻 $t-\Delta t$ での加速 度応答に関する Taylor 展開式から，次のように求めら れる。

$$
\left\{u_{s}^{(4)}\right\}_{t}=\frac{1}{\Delta t^{2}}\left[\left\{\ddot{u}_{s}\right\}_{t-\Delta t}+\left\{\ddot{u}_{s}\right\}_{t+\Delta t}-2\left\{\ddot{u}_{s i t}\right] .\right.
$$

式（16）に式（17）を代入し, 時刻 $t+\Delta t$ の変位応 答を求めると,

$$
\begin{aligned}
\left\{u_{s}\right\}_{t+\Delta t}= & -\left\{u_{s}\right\}_{t-\Delta t}+2\left\{u_{s}\right\}_{t}+\frac{\Delta t^{2}}{12}\left[\left\{\ddot{u}_{s}\right\}_{t-\Delta t}\right. \\
& \left.+\left\{\ddot{u}_{s}\right\}_{t+\Delta t}+10\left\{\ddot{u}_{s}\right\}\right] \ldots \ldots \ldots \ldots \ldots \ldots \ldots \ldots \ldots \ldots \ldots
\end{aligned}
$$

となる。一方, 時刻 $t+\Delta t$ の速度応答は次式のように 表すことができる。

$$
\left\{\dot{u}_{s}\right\}_{t+\Delta t}=\left\{\dot{u}_{s}\right\}_{t}+\frac{\Delta t}{2}\left[\left\{\ddot{u}_{s}\right\}_{t}+\left\{\ddot{u}_{s}\right\}_{t+\Delta t}\right]
$$

式（18）（19）を式（1）に代入し，時刻 $t+\Delta t$ の加速 度応答 $\left\{\ddot{u}_{s}\right\}_{t+\Delta t}$ について代数方程式を解くと,

$$
\begin{aligned}
\underline{\left\{\ddot{u}_{s}\right\}_{t+\Delta t}}= & {[S]^{-1}\left[\{F\}_{t+\Delta t}+\underline{\left\{\alpha \mid D_{h y d}^{*}\right.}+[C]\left(\left\{\dot{u}_{s}\right\}_{t}+\frac{\Delta t}{2}\left\{\ddot{u}_{s}\right\}_{t}\right)\right.} \\
& \left.+[K]\left(\Delta t^{2}\left\{\ddot{u}_{s}\right\}_{t}-\frac{\Delta t^{2}}{12}\left\{\Delta \ddot{u}_{s}\right\}_{t}+\left\{\Delta u_{s}\right\}_{t}\right)\right]
\end{aligned}
$$

となる。ここに，

$$
[S]=[M]+\frac{\Delta t}{2}[C]+\frac{\Delta t^{2}}{12}[K] \cdot \cdots
$$

でありまた，

$$
\left.\begin{array}{l}
\left\{\Delta u_{s \mid t}=2\left\{u_{s}\right\}_{t}-\left\{u_{s}\right\}_{t-\Delta t}\right. \\
\left\{\Delta \ddot{u}_{s}\right\}_{t}=2\left\{\ddot{u}_{s}\right\}_{t}-\left\{\ddot{u}_{s}\right\}_{t-\Delta t}
\end{array}\right\}
$$

である。式 (20) より, 時刻 $t$ および時刻 $t-\Delta t$ の応 答で時刻 $t+\Delta t$ の加速度応答 $\left\{\ddot{u}_{s}\right\}_{t+\Delta t}$ が求められる。ま た，時刻 $t+\Delta t$ の変位 $\left\{u_{s}\right\}_{t+\Delta t}$ および速度 $\left\{\dot{u}_{s}\right\}_{t+\Delta t}$ につ いては，それぞれ式 (18)（19）から求めることができる。 ただし, 式 (20) の TLD の流体力 $D_{h y d}^{*}$ は, 時刻 $t$ $+\Delta t$ における值であり, 同時刻の加速度応答 $\left\{\ddot{u}_{s}\right\}_{t+\Delta t}$ の 関数である。したがって，構造系の加速度応答と TLD の流体力は時刻 $t+\Delta t$ において同時に求める必要があ る。ここでは, 前時刻ステップの流体力 $D_{h y d(t)}$ を初期 值とし，時刻 $t+\Delta t$ におけるTLD の流体力 $D_{h y d(t+\Delta t)}$ と構造系の加速度灾答 $\left\{\ddot{u}_{s}\right\}_{t+\Delta t}$ の間で収束計算を行い, その収束值を時刻 $t+\Delta t$ における TLD の流体力 $D_{h y d}^{*}$ として求めることにした。収束計算の判定条件式として
は，

$$
\left|\frac{D_{h y d(t+\Delta t)}^{(n)}-D_{h y d}^{(n-1)}(t+\Delta t)}{D_{h y d(t)+\Delta t)}^{(n-1)}}\right| \leq \epsilon
$$

を用い，上式の条件を満足した時の $D_{h y d(t+\Delta t)}^{|n|}$ を時刻 $t$ $+\Delta t$ における TLD の流体力の収束值 $D_{h y d}^{*}$ とする。な お， $n$ は収束計算の繰り返し回数である。

本研究の積分スキームの安定条件について検討するた め, 線形 1 自由度の質点系に対する数值実験を行った。 その結果, 応答の積分が発散しない絶対安定な条件とし て，構造系の固有周期 $T_{\min }$ に対して，

$$
\frac{T_{\min }}{\Delta t}>\pi
$$

であり, 応答の厳密解と比較して十分な精度を持つには, さらにその $1 / 3$ 程度の $\Delta t$ が必要となる。

\section{3. 相互作用モデルの定常応答解析}

本研究で開発した相互作用モデルの妥当性を検証する ため, P. Chaiseri, Y. Fujino ら ${ }^{171,18)}$ による TLD-構 造系の強制振動実験結果のうち, 非砕波状態の実験結果 と本解析結果を比較する。

P. Chaiseri, Y. Fujino らの振動実験では, せん断 振子夕イプの1自由度の構造系（プラットフォーム）に TLD 容器と加振器をのせ, 加振力を一定に制御した状 態で加振円振動数 $\omega$,を変化させ, 定常状態に達した時 の構造系の変位応答 $u_{s}$ 亡 TLD 容器内部の液面変動量 $\eta$ を測定している ${ }^{17), 18) 。 ~}$

実験に用いられた 1 自由度の構造系は, 質量 $m_{s}=$ $168 \mathrm{~kg}$, 固有周期 $T_{s}=1.1 \mathrm{~s}$ および減衰定数 $\beta_{s}=0.32$ \%である。また, TLD 容器は, 振動方向幅 $L=25.2 \mathrm{~cm}$, 奥行き幅 $b=32.2 \mathrm{~cm}$ の矩形容器である。内容液は水と し, 水深は構造系の固有周期 $T_{s}=1.1 \mathrm{~s}$ 亡同調させるた め $h=2.1 \mathrm{~cm}$ としている。この場合, TLD 内容液と構 造系の質量比は, $\mu\left(=m_{L} / m_{s}\right)=1 \%$ となる。実験結 果亡解析結果を比較するため, 応答解析は実験と同様, 各加振振動数において静止状態から定常状態になるまで 行うものとする。なお，解析を実行する場合の要素分割 数は, 自由表面において $N_{F}=40$, 容器側壁で $N_{W_{1}}=N_{W_{2}}$ $=5$ とし, 時間增分量として $\Delta t \sqrt{g / h}=0.36$ を満足す るものとし ${ }^{23)}$, また, 式 (23) の収束判定精度として $\epsilon$ $=0.01$ とした。

Fig. 3 は, 構造系の変位に関する周波数応答曲線を示 したものであり，振動実験結果と本解析結果を比較した ものである。加振外力としては，TLDを設置しない状 態での共振振幅が $1 \mathrm{~cm}$ になるように制御している。図 中の $(○, \bigcirc)$ は, 加振開始より十分時間が経過した後 の 20 サイクル分の r.m.s. 值の $\sqrt{2}$ 倍の值をプロットし たもので, 図中（○）は本解析結果を表し, 図中 (O) が実験結果を表している。加振振動数比 $f / f_{s}=0.96$ 


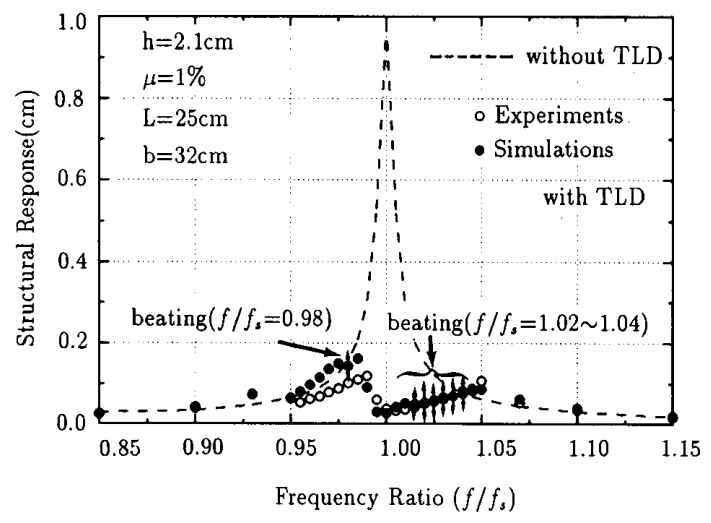

Fig. 3 Frequency Response Curves

0.98 付近で実験結果より解析結果が大きめの值を示す が，それ以外では両者の対応は極めて良好であり，本研 究における応答解析法が妥当であることがわかる。また， 共振振動数付近では, TLD を設置することにより構造 系の态答が $10 \%$ 20\% 程度に低減されており，TLD の有効性が確認できる。

Fig. 3 の加振振動数比 $f / f_{s}=0.96 \sim 0.98$ 付近で解析 結果が実験結果より大きな值となる理由の一つとして, 式（8）で評価した減衰係数が実際よりも小さかったこ とが考えられる。特に, 式（8）の第 2 項は, 容器側壁 の境界層が減衰に寄与する影響を幾何学的に評価したも のであるが, 本研究において比較の対象とした容器は水 深 $h$ に対して奥行き幅 $b$ が大きく，式（8）の第 2 項 が減衰係数 $\gamma$ に寄与する割合が極めて小さい。このこ とが原因で，実際よりも減衰を過小評価することにつな がったものと考えられる。

Fig. 4 およびFig. 5 は, Fig. 3 の加振振動数比 $f / f_{s}$ $=0.960 \sim 1.040$ における構造系の変位応答 $u_{s}$ と TLD 容器内部の液面変動量 $\eta$ の時系列（静止状態から 200 秒間）を表したものである。 $f / f_{s}=0.98$ と $f / f_{s}=1.02$ の波形に顕著なビート現象が見ることができる。同様な ビート現象が，P.Chaiseri，Y．Fujinoらの実験にお いても $f / f_{s}=1.015 \sim 1.040$ の間で観察されており，ま た, 矩形容器内の液体の非線形振動に関する Lepelletier and Raichen の研究25) でも $f / f_{s}=0.98$ 付近におい てビート現象が観察されている。

Fig. 6 は, 液面動摇の非線形性について検討するため, 共振振動数付近 $\left(f / f_{s}=0.98 \sim f / f_{s}=1.02\right)$ の液面変 動量 $\eta$ のフーリエスペクトルを表したものである。い ずれのスペクトルにも，加振振動数成分Peak (1) 以 外に液面動摇の非線形性に伴亏高調波成分 Peak (2) が顕著に現れている。また，Fig. 4 およびFig. 5 の f/ $f_{s}=0.98$ と $f / f_{s}=1.02$ 波形で見られたビート現象は,

Fig. 6 のスペクトル上で見た場合, 卓越振動数成分に近 接する振動数成分の存在で確認できるが, Fig.6の f/ $f_{s}=0.98$ と $f / f_{s}=1.02$ のスペクトルにも, 加振振動数

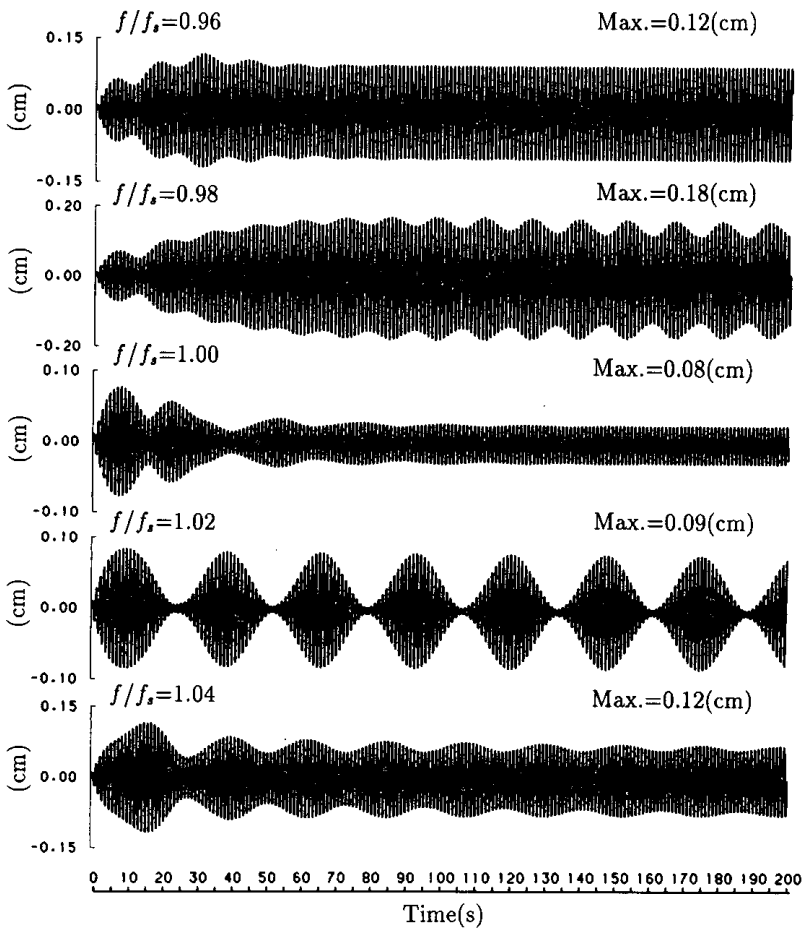

Fig. 4 Time History of Structural Response $u_{s}(\mathrm{~cm})$

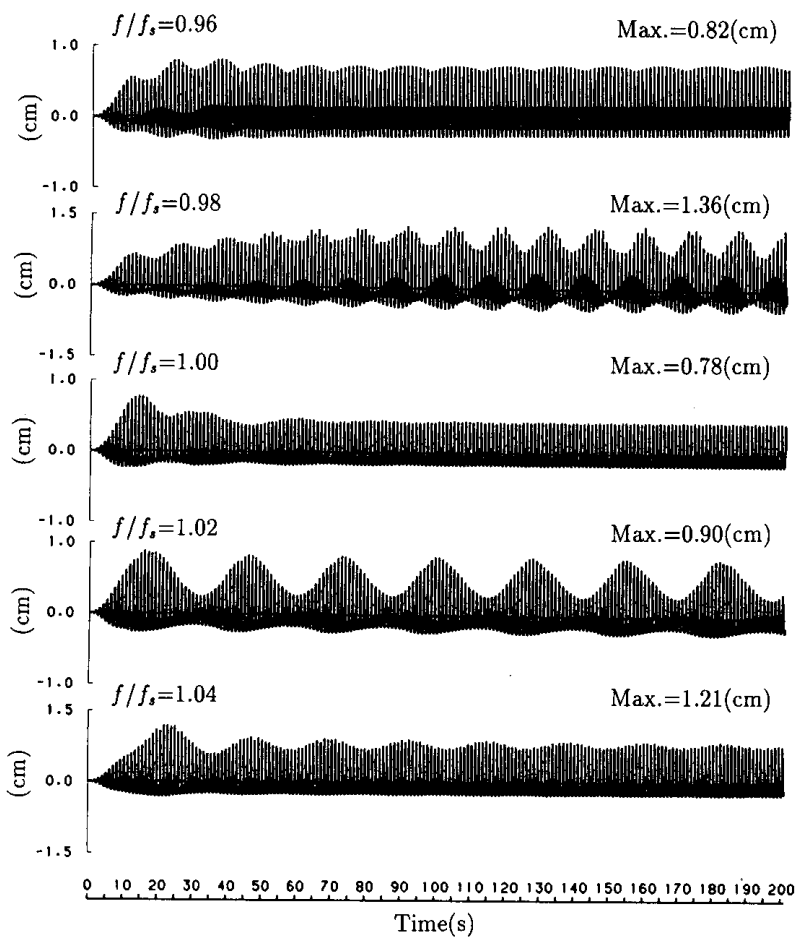

Fig. 5 Time History of Surface Elevation $\eta(\mathrm{cm})$

成分および高調波成分に近接した振動数成分Peak（3） を見ることができ，この振動数成分の存在が前述した ビート現象の原因になっていると考えられる。

共振振動数付近に生じるビート現象は, Lepelletier らの実験結果や解析結果に基づく考察から，浅い液体の 非線形振動に伴う現象であり，TLD-構造系の連成効果 によって生じるものではないことがわかっている251。 P. Chaiseri, Y. Fujinoらは,このビート現象の原因 

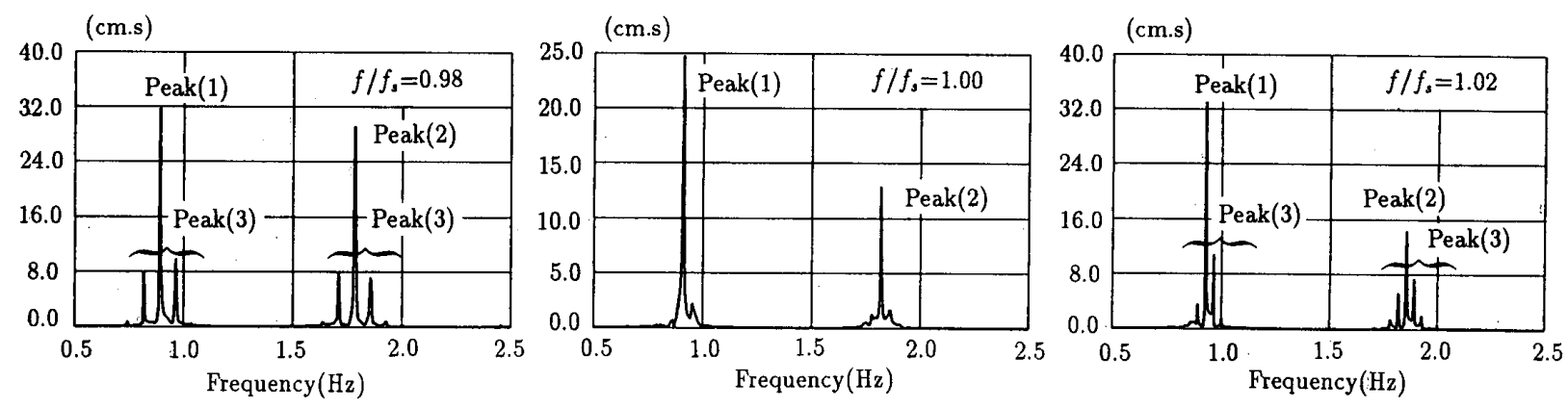

Peak(1) : Excitation Frequency Component $f$

Peak(2) : Harmonic Component $\hat{f}_{n}=n \cdot f(n=1,2, \ldots)$

Peak(3) : Frequency Component due to Beating Response

Fig. 6 Fourier Spectra of the Surface Elevation

として, 実験において生じた容器内の 3 次元的な流体運 動に起因する面外振動の応答成分（cross wave）あるい は非線形内部共鳴（nonlinear self-interaction）が原因 であると考察している ${ }^{17), 18) 。 ~}$

しかし, 本研究の解析結果や Lepelletier ${ }^{25)} ら の 2$ 次 元的な解析モデルを用いた数值計算結果においても, 顕 著なビート現象が生じていることから, 少なくとも面外 振動の影響で生じる現象ではなく, 液面動摇の非線形性 に伴うある種の共鳴現象によるものと考えたほうが妥当 であろう。たとえば, 各種のモード間に生じる振動工ネ ルギーのやりとり (再帰現象) が原因として考えられる が28), このビート現象に関するより厳密な考察は, 今後 の検討課題の一つとする。

このような検討結果から, 共振振動数付近の夜面動摇 の非線形特性として, 高調波成分の発生とある種の共鳴 現象によって引き起こされるビート現象の存在が挙げら れる。

\section{4. 非定常外力に対する制振効果}

\section{1 解析条件}

横浜マリンタワーに対して時系列風応答解析を行い, 定常ランダムな外力に対する本解析法の適用性と TLD の制振効果とその減衰特性の関係について検討する。

Fig. 7 に示すように，横浜マリンタワーは高さ101.3 $\mathrm{m}$, 総質量 $440 \mathrm{t}$ のトラス構造の高層夕ワーである。マ リンタワーでは, TLD を設置する前後で風観測を実施 している。風観測は, 地上 $105 \mathrm{~m}$ の位置で風向および 風速を計測し, 高さ $99 \mathrm{~m}$ の位置にあるライトハウスに おいて, 図中 $x$ および $y$ 方向の横摇れ振動を加速度計 で計測するものである。実測結果に基づくマリンタワー の振動特性は, 1 次固有周期 $T_{s}^{(1)}=1.8 \mathrm{~s}$, 减衰定数 $h_{s}^{(1)}$ $=0.6 \%, 1$ 次振動モードに対する一般化質量 $M_{s}^{(1)}=157$ $\mathrm{t}$ である31。ただし，モ一ド・ベクトルとして，最大值 で規準化した場合の值を用いている。

これらの振動特性を考慮し, Fig. 7 に示すような 6 質 点の多質点ば゙ね系にモデル化する。構造諸元より各質
点に相当する質量を定め, また, 実測された固有周期が 一致し, かつ, 基本モード形状が相似となるように解析 モデルの剛性分布を決定した。减衰は 1 次のモード减衰 が実測値に一致するような剛性比例型の减衰を仮定し た。各質点の高さ $H_{n}$, 質量 $M_{n}$, 剛性 $K_{n}$ および見附面 積 $A_{n}$ は，それぞれ Table 1のようにまとめられる。

マリンタワーには, 地上 $99 \mathrm{~m}$ のライトハウスに, 直 径 $D=49 \mathrm{~cm}$, 高さ $H=50 \mathrm{~cm}$ の円筒形で高さ方向に 5 $\mathrm{cm}$ 間隔で 10 層に仕切られた TLD が 39 ユニット（ $N_{D}$ $=39 \times 10 ）$ 設置されている。内容液は水とし, スロッシ ングの基本固有周期 $T_{L}\left(=2 \pi / \omega_{L}\right)$ がマリンタワーの 1 次固有周期と同調するように, 液深 $h$ を $2.1 \mathrm{~cm}$ に設 定している。この場合，一般化質量 $M_{s}^{(1)}=157 \mathrm{t}$ に対す る質量比は $\mu=1 \%$ である ${ }^{2), 3) 。 ~}$

ところで, 本研究で用いている TLD の流体解析モデ ルは, 2 次元的な流体運動を解析するもので, 円形断面 を有する容器には直接対応することはできない。ここで は, 円形容器と矩形容器の液深 $h$ が等しい条件式,

$$
\underbrace{\frac{D}{3.674} \tanh ^{-1}\left(\frac{4 \pi^{2} D}{3.674 T_{L}^{2} g}\right)}_{\text {円形容器 }}=\underbrace{\left.\frac{L}{3.141 T_{L}^{2} g}\right)}_{\text {矩形容器 }}
$$

に同調周期 (スロッシングの基本固有周期) $T_{L}$ が等しく, 液体質量 $m_{L}$ が等しい条件を考慮し，次式で表される矩 形容器 $(L \times b)$ に置換する。

$$
L=\frac{3.141}{3.674} D, \quad b=\frac{\pi}{4 L} D^{2}
$$

TLD の制振効果とは，TLD 設置以前の応答レベル をTLDの設置により相対的によ゙れだけ低減できたかを 表すものである。いま, 解析で求められる TLD の制振 効果が, 風観測の結果と一致するかどうかを検討する場 合, 応答解析用の入力として, TLD 設置以前のマリン タワーの観測值と等しい応答を与える変動風力の時系列 を仮定する必要がある。

本研究では, 田村ら ${ }^{291}$ の方法により, マリンタワーに 作用する風方向の変動風力を評価することにする。この 方法は, 任意のパワースペクトル密度と空間相関を持つ 


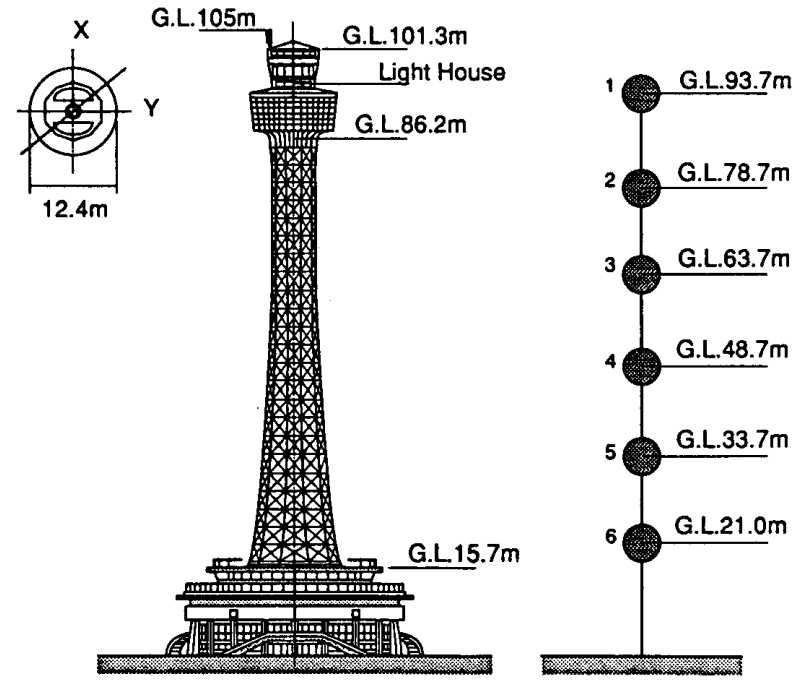

Fig. 7 External Appearance and MDOF Model of the Yokohama Marine Tower

Table 1 Analytical Data of Marine-Tower

\begin{tabular}{c||c|c|c|c}
\hline No. & Height & Mass & Stiffness & Face-Area \\
& $H_{n}(m)$ & $M_{n}(t)$ & $K_{n}(\times 9.8 k N)$ & $A_{n}\left(m^{2}\right)$ \\
\hline 1 & 93.7 & 156.4 & 612.3 & 141.0 \\
2 & 78.7 & 28.6 & 765.3 & 103.0 \\
3 & 63.7 & 34.3 & 918.4 & 109.0 \\
4 & 48.7 & 72.8 & 2448.0 & 125.0 \\
5 & 33.7 & 82.6 & 6122.5 & 161.0 \\
6 & 21.0 & 64.6 & 12244.9 & 145.0 \\
\hline
\end{tabular}

変動風速を模擬できる岩谷 ${ }^{301}$ の自己回帰法を多少修正 し，構造系に作用する風方向変動風力を求めるものであ る。なお，その詳紐は文献 291,301 に譲るものとする。

変動風力を評価する際に用いた主要な条件としては, 平均風速の鉛直分布はべき指数 $\alpha=1 / 7$ に従うもの亡 し, 動的風力係数 $C_{D}=0.7$ (円柱を仮定), 見附面積は Table 1 の值とする。時間刻み $\Delta t=0.05$ で 5800 デー 夕の時系列を発生させ、はじめの 1000 データを無視し て 240 秒間 (4800 デー夕) の変動風力デー夕を求める ことにする。応答解析では式 (24) を満足するように $\Delta t$ を 5 分割し, 変動風力デー夕を線形補完の後, $\Delta t /$ $5=0.01$ を時間增分として直接積分を行う。

ただし，この条件で求めた変動風力は, 実際の観測值 よりもかなり大きな応答解析結果を与えるため,ここで は，TLD 設置以前のマリンタワーの応答観測值とほぼ 等しい解析結果を与えるような振幅補正係数 $\phi_{A}$ を新た に定義し，以下のような振幅補正を行っている。

TLD 設置以前の観測值 (加速度応答の r. m. s. 值) $A_{r m s}$ 之高さ $105 \mathrm{~m}$ での平均風速 $V_{a v e}$ の関係は, 次式で 示されている3!。

$$
A_{r m s}=10^{-4.151} V_{\text {ave }}^{3.142}
$$

応答解析の結果がこの関係を満足するように, 平均風速 $V_{\text {ave }}=12 \mathrm{~m} / \mathrm{s} \sim 27 \mathrm{~m} / \mathrm{s}$ の変動風力デー夕に対して, 振
幅補正係数 $\phi_{A}=0.20 \sim 0.35$ を用いる。

4.2 解析結果

応答解析は, 地上 $105 \mathrm{~m}$ の位置（風速計設置位置） における平均風速 $V_{a v e}$ が $12 \mathrm{~m} / \mathrm{s} \sim 27 \mathrm{~m} / \mathrm{s}$ の場合につい て行う。

Fig. 8 は，マリンタワーに対する風観測結果と本解析 結果を比較したもので，ライトハウス（質点1）位置の 加速度応答の r.m.s. 值 $A_{r m s}$ を表している。本解析に よる TLD の制振効果は, 風観測記録と比較し, 平均風 速 $V_{a v e}=25 \mathrm{~m} / \mathrm{s}$ 以上ではやや過大評価気味であるが, それ以外では，極めて良く一致したものとなっている。 また, Fig. 8 から TLD の有効性が確認でき，比較的低 風速域である $V_{a v e}=15 \mathrm{~m} / \mathrm{s}$ 前後では低減率 $1 / 2$ 程度, 高風速域の $V_{a v e}=27 \mathrm{~m} / \mathrm{s}$ 付近では低減率 $1 / 3$ 程度の制 振効果が得られている。

一般的に，TLD は TMD 等のダイナミックダンパー 之同様，制振効果を最も効率よく発揮できる最適な堿衰 定数 $\beta_{\text {opt }}$ が存在する。建設分野で取り扱う構造物を想 定すると，たとえばTMD の場合には質量比 $\mu$ の関数 として以下のように表すことができる311。

定常ランダム外力の場合 : $\beta_{o p t}=\sqrt{\mu} / 2$

内容液に水だけを用いたTLD の等価減衰定数 $\beta_{L}$ $\left(=\gamma_{L} / 2 \omega_{L}\right)$ は, $\beta_{o p t}$ と比較して小さいが, 忘答振幅 が増加し液面変動量が増加すると, TLD 容器内の液面 動摇の非線形性による影響で，見かけ上の TLD の等価 減衰定数 $\beta_{L}$ が増加し, 式 (27) で定義するような最適 減衰定数 $\beta_{\text {oot }}$ に近づく傾向にある。その結果, 低風速 レベルと比較し，高風速レベルではより高い制振効果を

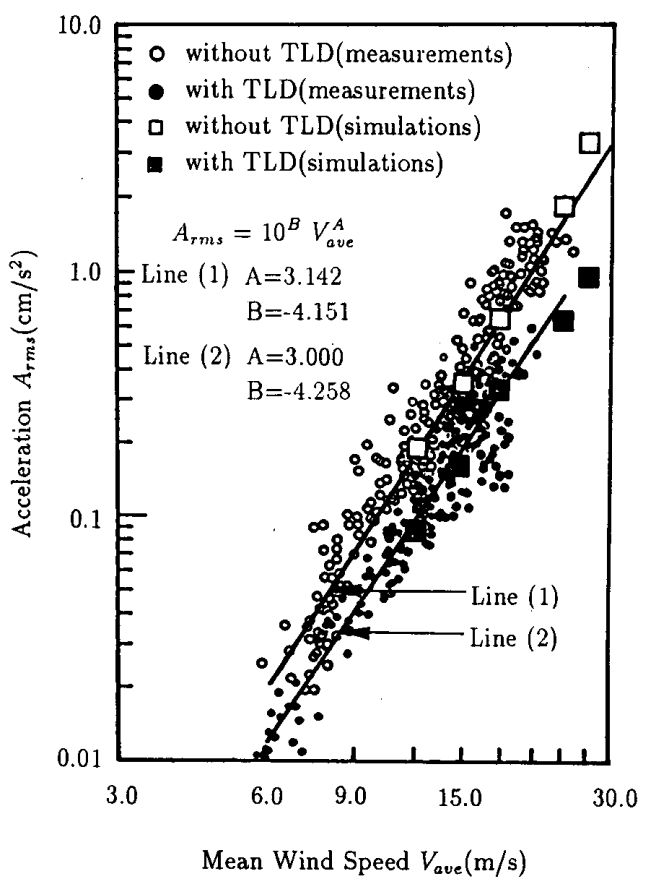

Fig. 8 Effect of the TLDs on the Acceleration Response of the Yokohama Marine Tower 
得ることができる ${ }^{34)}$ 。

Fig. 9 は, $V_{\text {ave }}=15 \mathrm{~m} / \mathrm{s}$ と $V_{a v e}=27 \mathrm{~m} / \mathrm{s}$ の場合の加 速度応答 $\ddot{u}_{s}$, 設置した 39 ユニット分の TLD の流体力 $D_{h y d}$ および液面変動量 $\eta$ の時系列波形を表したもので ある。TLD の効果によりマリンタワーの応答が抑えら れている状況がよく理解でき，その有効性が確認できる。 また, TLD の流体力 $D_{h y d}$ および液面変動量 $\eta$ の時系 列変化がよく表されている。

Fig. 9 において, 低風速域の $V_{a v e}=15 \mathrm{~m} / \mathrm{s}$ の流体力 $D_{h y d}$ と液面変動量 $\eta$ はほぼ線形的な特性を示している のに対し, 高風速域の $V_{a v e}=27 \mathrm{~m} / \mathrm{s}$ の流体力 $D_{h y d}$ 亡液 面変動量 $\eta$ は, 非線形性を帯びた応答特性となってい ることがわかる。

Fig. 10 は, 液面動摇の非線形性が, 構造系の応答に 及ぼす影響を調べるため, 高風速域（平均風速 $V_{a v e}=$ $27 \mathrm{~m} / \mathrm{s})$ での加速度応答 $\ddot{u}_{s}$, 流体力 $D_{h y d}$ および液面変 動量 $\eta$ の正規化パワースペクトル（総面積で規準化） を表したものである。

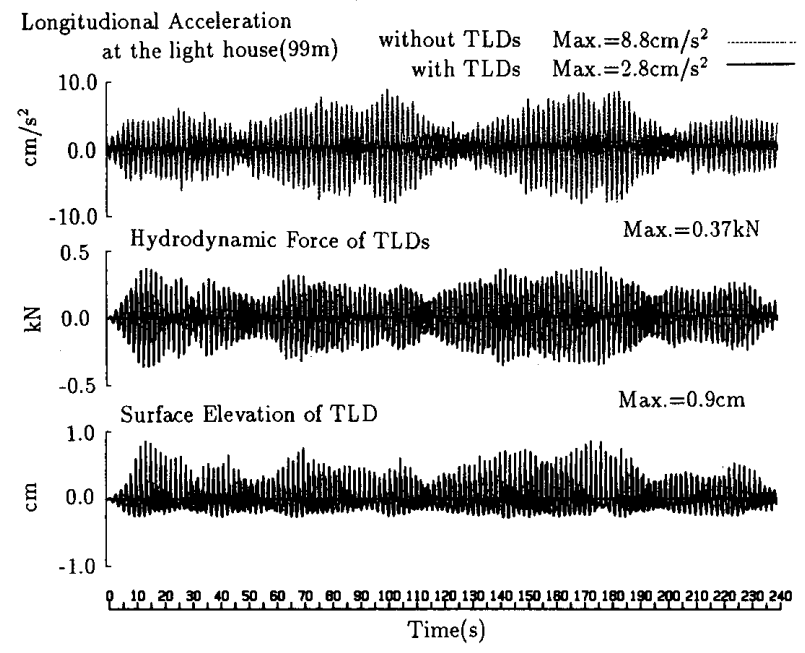

(a) High Windspeed Range $V_{a v e}=27 \mathrm{~m} / \mathrm{s}$

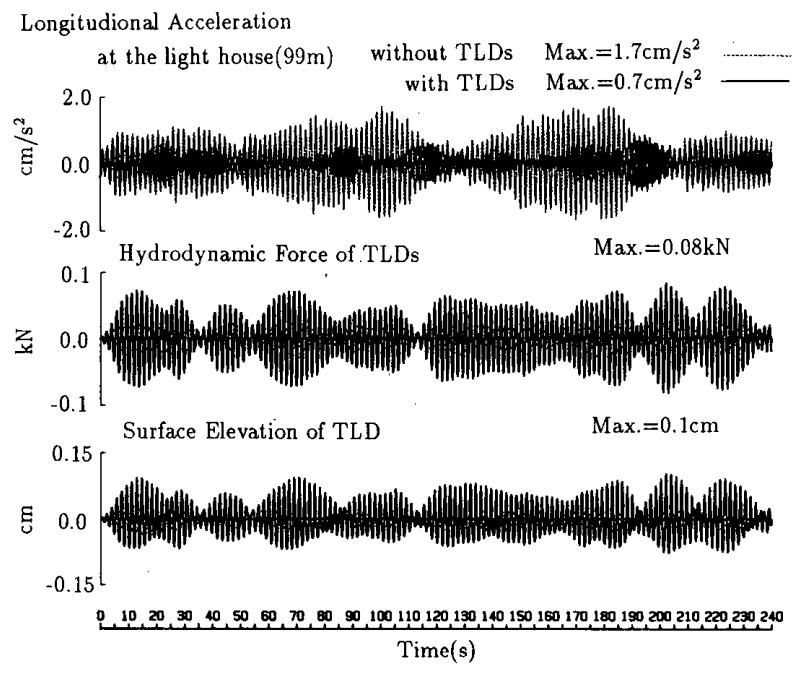

(b) Low Windspeed Range $V_{\text {avc }}=15 \mathrm{~m} / \mathrm{s}$

Fig. 9 Time History of Response of the Yokohama Marine Tower

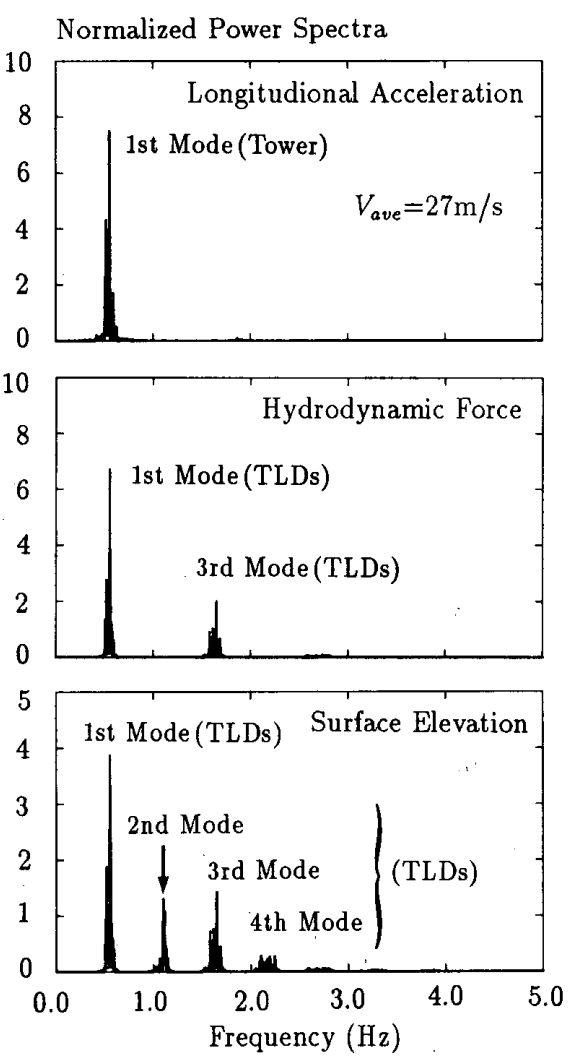

Fig. 10 Normalized Power Spectra of Response

液面変動量 $\eta$ のパワースペクトルには, 液面動摇の 基本固有振動数成分とともに高次振動数成分 ( 2 次, 3 次, 4 次…) が顕著に現れている。これは, 次式で示すよう に, 液面動摇の非線形性によって生じた高調波の振動数 （基本固有振動数の 2 倍， 3 倍，4 倍成分 $\cdots$ ）が, 液面 動摇の高次振動数に近接しているためであり，この高次 振動数成分が, 非線形性による高調波成分によって励起 されたものであることがわかる。

$$
\begin{aligned}
& n f_{L} \simeq \underbrace{\sqrt{\frac{n g}{4 \pi L} \tanh \left(\frac{n \pi h}{L}\right)} \quad(n \geq 2)}_{\text {液面動摇の高次振動数 }} \\
& f_{L}=\frac{\omega_{L}}{2 \pi} \quad\left(f_{L}: \text { 液面動摇の基本固有振動数 }\right)
\end{aligned}
$$

また, 流体力 $D_{h y d}$ のパワースペクトルでは, 対称モー ドとなる偶数次の高次振動数成分は存在せず, 基本固有 振動数成分と 3 次の高振動数成分が卓越する。

一方, マリンタワーの加速度応答 $\ddot{u}_{s} に は$, 構造系の 1 次固有振動数成分のみが卓越するだけであり, 液面動 摇の非線形性によって生じる高次振動数成分は存在しな い。これは, マリンタワー側に液面動摇の高次振動数成 分 (この場合, 3 次振動数成分) に対応する高次振動モ一 ドが存在しないためであり, その結果, ほとんどが基本 振動モード（1 次成分）で応答する状態となっている。

通常, 風外乱に対する振動制御は，1次卓越型の振動 特性を有する構造物を対象とする場合が多く，上記の考 
察結果と同様, 液面動摇の非線形性に伴う高次振動数成 分が, 構造物の応答に影響を及ぼすことはほとんよ゙ない ものと考えられる。ただし，TLDを設置する構造物側 に, 液面動摇の奇数次の高次振動数に近い固有振動モ一 ドが存在し，そのモ一ド減衰が小さい場合には，非線形 性による液面動摇の高次振動数成分が構造物側の高次振 動モードに影響する可能性があり，注意すべきことと考 えられる。

\section{5. 結 論}

ランダムな外力に対する TLD-構造系の動的応答を評 価し, TLD の制振効果を予測する時系列の風応答解析 法について検討した。また，砕波を生じない範囲での液 面動摇の非線形性とその非線形性が構造系に与える影響 について考察した。これらの結果をまとめると以下のよ うになる。

(1) 本研究で提案するTLD-構造系の相互作用モデル による定常応答解は, 定常調和外力に対する振動実験結 果と良く一致しており，BEMによる非線形波動解析を TLD の解析に応用した相互作用モデルは妥当なもので あることがわかる。

（2）マリンタワーに対する風観測記録と風応答解析結 果の比較から, TLD の制振効果をほぼ正確にシミュ レートでき, 定常ランダムな風外力に対する応答解析に も十分適用できる。

（3）低風速域 $\left(V_{a v e}=15 \mathrm{~m} / \mathrm{s}\right)$ では, TLD 設置以前 と比較し低減率 $1 / 2$ 程度の制振効果であるが, 風速が上 昇し高風速域になると低減率 $1 / 3$ 程度の制振効果とな る。これは, 応答振幅の増加による TLD 容器内の液面 動摇の非線形性の影響で, TLD の見かけの減衰定数 $\beta_{L}$ が増加し, ダイナミックダンパーの最適減衰定数 $\beta_{\text {opt }}$ に近づいたためである。

（4） TLD-構造系の共振振動数付近の振動特性とし て, 液面動摇の非線形性に伴う高調波成分の発生と, あ る種の共鳴現象によって励起されるビート現象が, 限定 された振動数帯域で生じうる。

（5）風外乱に対する振動制御は，1 次卓越型の振動特 性を有する構造物を対象とする場合が多く, 液面動摇の 非線形性に伴う高次振動数成分がTLD を設置した構造 物の応答に影響を及ぼすことはほとんゼない。ただし， TLD を設置する構造物側に, 液面動摇の奇数次の高次 振動数に近い固有振動モ一ドが存在し, そのモ一ド減衰 が小さい場合には，非線形性による液面動摇の高次振動 数成分が構造物側の高次振動モードに影響する可能性が 考えられる。

本研究では, 砕波を生じるまでの液面動摇の非線形性 を考慮した TLD-構造系の連成応答解析について検討し た。今後，砕波を伴うようなより大きな振幅を対象にす
る場合には，振動実験に基づく半経験的ルールに従う解 析モデルを設定する必要があろう。

また，今回のマリンタワーに対する応答解析は，円筒 容器を矩形容器に置換し 2 次元的な解析モデルを用いて の応答解析であったが, 今後, 適切なクライテリアのも とに，より厳密な考察を行うためにも， 3 次元の流体解 析モデル ${ }^{221}$ による多方向加振条件下での応答解析も行う 必要がある。

さらに, 風外乱による構造系の応答評価に関連して, 構造物に作用する変動風圧力の評価, 構造系自体の減衰 評価などの基本的な検討課題が残されている。今後,こ れらの課題について検討し, 構造物に対するTLD の最 適設計を解析的に行えるようにしなければならない。

\section{謝 辞}

本研究を進めるにあたり, 東京大学工学部 藤野陽三 教授には，貴重なご意見を賜っている。ここに記して深 謝の意を表します。

\section{参考文献}

1) Modi, V.J. and F. Welt : Vibration Control using Nutation Dampers, Proc. Int. Conf. on Flow Induced Vibration, England, pp. 396 376, 1987.

2）藤井邦雄, 佐藤孝典, 大筑民夫：液体のスロッシングを 利用した制振装置一Tuned Sloshing Damperについて 一, 日本建筑学会大会学術講演梗概集 B, pp. 1483 1484, 1987 年.

3) Tamura, Y., Fujii, K., Sato, T., Wakahara, T. and Kosugi, $\mathrm{M}:$ Wind-Induced Vibration of Tall Towers and Practical Applications of Tuned Sloshing Damper, Proc. Symposium; Workshop on Serviceability of Building, Canada, pp. 228 241, 1988.

4）藤井邦雄, 大築民夫, 佐藤孝典：液体のスロッシングを 利用した制振装置 (Tuned Sloshing Damper) の実証実 験一横浜マリンタワーの風による振動の制振効果など一, 日本建築学会大会学術講演梗概集 B, pp. $561 ５ 62$, 1988 年.

5) Fujino, Y., Pacheco, B. M., Chaiseri, P. and Sun, L. M. : Parametric Studies on Tuned Liquid Damper (TLD) Using Circular Tanks by Free-oscillation Experiments, Structural Eng./Earthquake Eng., JSCE., Vol. 5, No. 2, pp. 381s -391s, 1988 (Proc. of JSCE No. $398 / \mathrm{I}-10)$.

6）野路利幸, ほか：スロッシングを利用した制振装置の研 究（その1〜その 16 ), 日本建築学会大会学術講演梗概集 B, pp. $867 \sim 874,1987$ 年, pp. $563 \sim 570,1988$ 年, pp. $615 \sim 622,1989$ 年, pp. $905 \sim 914,1990$ 年.

7) 宮田利雄, 山田 均, 斉藤善昭: 長方形水槽ダンパー適 用に関する諸問題の検討，構造工学論文集，No. 35 A, pp. $553 \sim 560,1989$ 年.

8) 坂井藤一, 高枝新伍, 玉木利裕: 液柱管ダンパー(Tuned Liquid Column Damper) の提案-被柱管の振動特性-, 構 造工学論文集, No. 35 A, pp. 543 552, 1989 年.

9）米田昌弘, 藤野陽三，ほか：幸魂橋主塔に対する 
T.L.D.の減衰付加効果について, 日本風工学会誌, No. 41, pp. 105 106, 1989 年.

10）山岸一彦, 西本 聡, 植田利夫, 中垣亮二, ほか：TSD による斜張橋・塔の制振効果, 土木学会第 45 回年次学術 講演会概要集, 第 1 部, pp. 956 957, 1990 年.

11）野路利幸，ほか：水のスロッシングを利用した制振装置 の高層建物への適用研究, 日本建築学会関東支部, 制振 構造の現状一高層建物の制振一, pp. 51 -56, 1989 年.

12）萩生田弘：水のスロッシングを利用した制振装置, 三井 造船技報, Vol. 137, pp. 13 20, 1989 年.

13）中垣亮二, 植田利夫, 有馬健次, 加道博章 : Tuned Sloshing Damper $の$ 振動特性之制振効果, 構造工学論文 集, No. 36 A', pp. 591 602, 1990 年.

14）野路利幸, 吉田英敏, 立見栄司, 小坂英之, 萩生田弘： 水のスロッシングを利用した制振装置の研究, (その 1 ) 装置の流体力特性と制振効果の特性, 日本建築学会構造 系論文報告集, 第 411 号, pp. 97 105，1990 年.

15）藤野陽三，パチェコベニート，チャイセリピヤワット， 藤井邦雄：TLD の基本特性に関する実験的検討, 構造工 学論文集, No. 34 A, pp. 603 616, 1988 年.

16) Sun, L. M., Fujino, Y., Pacheco, B. M. and Isobe, M. : Nonlinear Waves and Dynamic Pressures in Rectangular Tuned Liquid Damper (TLD)-Sinulation and Experimental Verification-, Structural Eng./Earthquake Eng., JSCE., Vol. 6, No. 2, pp. 251s 262s, 1989 (Proc. of JSCE No. 410/ I-12).

17) Chaiseri, P., Fujino, Y., Pacheco, B. M. and Sun, L. M. : Interaction of Tuned Liquid Damper (TLD) and Structure-Theory, Experimental Verification and Application-, Structural Eng. /Earthquake Eng., JSCE., Vol. 6, No. 2, pp. 273s $\sim 282$ s, 1989 (Proc. of JSCE No. $410 /$ I-12).

18）藤野陽三, パチェコベニート, 孫 利民, チャイセリピ ヤワット, 磯部雅彦：同調夜体ダンパーに関する非線形 波動シミュレーションとその実験的検証一長方形容器の場 合-, 構造工学論文集, No. 35 A, pp. 561 - 574, 1989 年.

19）藤野陽三, パチェコベニート, チャイセリピヤワット, 係 利民，古賀健一：TMD アナロジーをベースにした TLD の特性の理解, 構造工学論文集, No. 36 A, pp. 577 ～590, 1990 年.

20）若原敏裕, 藤井邦雄 : T. L. D. 構造物系の風応答に関す る数值シミュレーション, 日本風工学会誌, No. 41, pp. 101 102, 1989 年.
21）大山 巧，藤井邦雄：2 次元非線形スロッシング問題の 境界要素解析, 構造工学論文集, No. 35 A, pp. 575 584, 1989 年.

22) 大山 巧：円筒容器内の非線形スロッシング現象の解析, 土木学会論文集, 第 417 号 / II -13, pp. 255 264, 1990 年.

23）大山 巧：数値波動水槽によるクノイド波の変形の解析, 第 33 会海岸工学講演概要集, pp. 99 103，1986 年.

24）清水 隆, 葉山眞治：浅水波理論を応用したスロッシン グの非線形応答（第 1 報, 基礎方程式の導出之長方形容 器における非線形応答), 日本機械学会論文集 ( C 編), 53 巻 486 号, pp. $357 \sim 363,1982$ 年.

25) Lepelletier, T. G, and Raichlen, F. : Nonlinear Oscillations in Rectangular Tanks, Jour. Eng. Mech., ASCE, pp. 1 23, 1988.

26) Miles, J. W. : Surface Wave Damping in Closed Basins, Proc. Roy. Soc. London, A 297, pp. 459 475, 1967.

27) Miles, J. W. : Resonantly Forced Nonlinear Gravity Waves in a Shallow Rectangular Tank, Wave Motion, Elsevier Science Publishers, B. V. (North Holland), Vol. 7, pp. 291 297, 1985.

28）戸田盛和：非線形格子力学一増補版一, 応用数学叢書, 岩波書店, 1987 年.

29）田村幸雄, ほか：高層建築物の時系列風応答解析につい $\tau$, 日本建築学会大会学術講演梗概集 B, pp. 143 144, 1988 年.

30）岩谷祥美：任意のパワースペクトルとクロススペクトル をもつ多次元の風速変動のシミュレーション, 日本風工 学会誌, No.11, pp. 5 18, 1982 年.

31) Warburton, G. B. : Optimum Absorber Parameters for Various Combinations of Response and Excitation Parameters, Earthquake Eng. and Structure Dyn., Vol.10, pp. $381 \sim 401,1982$.

32) Warburton, G. B. and Ayorinde, E. O. : Optimum Absorber Parameters for Simple Systems, Earthquake Eng. and Structure Dyn., Vol. 8, pp. 197 217, 1980.

33) Ayorinde, E. O. and Warburton, G.B. : Minimizing Structural Vibrations with Absorbers, Earthquake Eng. and Structure Dyn., Vol. 8, pp.219 236, 1980.

34）田村幸雄：付加振動体型パッシブシステム全体概要, 日 本建築学会関東支部, 制振構造の現状一高層建物の制 振一, pp. 33 44, 1989 年.

(1991 年 1 月 1 日原稿受理, 1991 年 6 月 14 日採用決定) 